\title{
UJI Brine Shrimp Lethality Test (BSLT) UMBI BAWANG TIWAI (Eleutherine bulbosa (Mill.) Urb) DAN UJI TOKSISITAS AKUT FRAKSI AKTIF
}

\author{
Dwi Lestari ${ }^{1}$, Rudi Kartika ${ }^{2}$, Eva Marliana ${ }^{3}$ \\ 1, 2, 3 Program Studi S2 Kimia Jurusan Kimia FMIPA Universitas Mulawarman \\ Email Korespondensi : rieka4827@gmail.com
}

\begin{abstract}
ABSTRAK
Eleutherine bulbosa (Mill.) Urb berasal dari keluarga Iridaceae, spesies ini mengandung metabolit sekunder dalam bentuk flavonoid dan kuinon. Metode penelitian ini meliputi uji toksisitas Brine Shrimp Lethality Test (BSLT) menggunakan larva Artemia salina Leach untuk menentukan nilai LC $_{50}$. Penelitian ini menggunakan metode eksperimental farmakologis menggunakan desain acak lengkap dalam pola arah yang sama dalam pemilihan hewan uji, 25 hewan yang digunakan adalah mencit putih dibagi menjadi 5 kelompok dengan 5 mencit per kelompok, dengan 4 jam diamati untuk mengetahui gejala toksik dan melanjutkan observasi setiap 24 jam untuk melihat kematian. Pengujian hasil BSLT menunjukkan bahwa ekstrak etanol memiliki toksisitas $\mathrm{LC}_{50}=66,68 \mathrm{ppm}$ (kategori sangat toksik), fraksi $n$-heksana memiliki toksisitas $\mathrm{LC}_{50}=$ 47,64 ppm (kategori sangat toksik), fraksi kloroform memiliki toksisitas $\mathrm{LC}_{50}=295,1$ ppm (kategori toksik), dan fraksi air memiliki toksisitas LC $_{50}=194,54$ ppm (kategori sangat toksik). Fraksi kloroform adalah fraksi aktif. Uji toksisitas akut nilai LD50 berdasarkan metode perhitungan Miller Tainter Probit (187,499 mg / KgBB), metode perhitungan Thompson Weil (182.810 mg / KgBB), cara menghitung Farmakope Indonesia $(187,068 \mathrm{mg} / \mathrm{KgBB})$. Berdasarkan tiga perhitungan, nilai $\mathrm{LD}_{50}$ berada dalam kategori sedang (50-500 mg / kgBB).
\end{abstract}

Kata kunci : Eleutherine bulbosa, BSLT, fraksi kloroform, uji toksisitas akut 


\section{ABSTRACT}

Eleutherine bulbosa (Mill.) Urb come from the Iridaceae family, this species contains secondary metabolites in the form of flavonoids and quinones. This research method includes Brine Shrimp Lethality Test (BSLT) toxicity using Artemia salina Leach larvae to determine the $L C_{50}$ value. This study used experimental methods pharmacologically using a completely randomized design in the same direction pattern in the selection of test animals, 25 animals used were white mice divided into 5 groups with 5 mice per group, with 4 hours observed to find out toxic symptoms and continued observation every 24 hours to see death. Testing of BSLT results showed that ethanol extract had $L C_{50}$ toxicity $=66.68 \mathrm{ppm}$ (very toxic category), $n$-hexane fraction had $L C_{50}$ toxicity $=47.64 \mathrm{ppm}$ (very toxic category), chloroform fraction had $L C_{50}$ toxicity $=$ $295.1 \mathrm{ppm}$ ( toxic category), and the water fraction has a toxicity of $L C_{50}=194.54 \mathrm{ppm}$ (very toxic category). The chloroform fraction is an active fraction. Acute toxicity test $L D_{50}$ value according to the calculation method of Miller Tainter Probit $(187,499$ $\mathrm{mg} / \mathrm{KgBB})$, the method of calculation of Thompson Weil $(182,810 \mathrm{mg} / \mathrm{KgBB})$, how to calculate Indonesian Pharmacopoeia $(187,068 \mathrm{mg} / \mathrm{KgBB})$. Based on the three calculations, the $L D_{50}$ value is in the medium category $(50-500 \mathrm{mg} / \mathrm{kgBB})$.

Keywords : Eleutherine bulbosa, BSLT, Chloroform fraction, Acute toxicity test

\section{PENDAHULUAN}

Obat tradisional atau obat-obatan bahan alami telah dikenal oleh masyarakat Indonesia sejak zaman dahulu dan digunakan secara turun temurun. Salah satu obat bahan alami yang digunakan adalah bawang tiwai karena secara empiris banyak digunakan oleh masyarakat Dayak dan Kutai sebagai pengobatan tradisional yang dapat mengobati aneka macam penyakit antara lain kanker usus, kanker payudara, diabetes melitus, hipertensi, menurunkan kolesterol, stroke, obat bisul, anti pendarahan dan sakit perut (Galingging, 2009).

Beberapa penelitian membuktikan bahwa bawang tiwai memiliki aktivitas antibakteri potensi sedang terhadap bakteri Escherichia coli, sebagai antioksidan dengan kategori kuat dan memiliki potensi sebagai agen antidiabetik yang bermanfaat dalam pencegahan dan perlindungan terhadap penyakit diabetes melitus (Amanda, 2014; Kuntorini, 2010; Febrinda, 2013). Umbi bawang tiwai berkhasiat sebagai obat. Bulbus (umbi lapis) bawang dayak atau bawang tiwai oleh masyarakat lokal Kalimantan banyak digunakan sebagai obat kanker payudara, gangguan jantung, dapat meningkatkan daya tahan tubuh, antiinflamasi, antitumor dan dapat menghentikan pendarahan. (Saptowaluyo, 2007).

Hasil beberapa penelitian pada umbi bawang tiwai memberikan informasi awal untuk dilakukannya penelitian lanjutan dengan cara ekstraksi senyawa pada fraksi aktif umbi bawang tiwai yang diduga potensial sebagai anti kanker. Lethal Concentration $50\left(\mathrm{LC}_{50}\right)$ 
adalah suatu perhitungan untuk menentukan keaktifan dari suatu ekstrak atau senyawa. Penggunaan $\mathrm{LC}_{50}$ ditujukan untuk uji ketoksikan dengan perlakuan terhadap larva udang. Kematian hewan uji digunakan untuk memperkirakan dosis kematian jika digunakan manusia (Priyanto, 2009). Apabila nilai $\mathrm{LC}_{50}$ dengan metode BSLT pada ekstrak tanaman bersifat toksik dapat dikembangkan sebagai obat antikanker (Carballo, 2002). BSLT pada penapisan senyawa-senyawa aktif yang terdapat dalam ekstrak tanaman yang ditunjukkan dengan melihat harga LC50 nya $\left(\mathrm{LC}_{50} \leq 1000 \mu \mathrm{g} / \mathrm{mL}\right.$ ) (Harmita dan Radji, 2008).

Uji toksisitas akut merupakan salah satu jenis pengujian toksisitas yang mengutamakan mencari efek toksik. Pengujian ini dilakukan dengan memberikan zat kimia yang sedang diuji sebanyak satu kali, atau beberapa kali dalam jangka waktu 24 jam. Uji toksisitas akut dapat menggunakan mencit. Tujuan uji toksisitas akut suatu obat adalah untuk menerapkan potensi toksisitas akut $\left(\mathrm{LD}_{50}\right)$, menilai berbagai gejala klinis, spektrum efek toksik, dan mekanisme kematian pada fraksi kloroforM umbi bawang Tiwai sebagai fraksi aktif.

\section{METODE PENELITIAN}

\section{A. Alat, Bahan dan Hewan uji}

\section{Alat}

Pisau, blender (Miyako), lampu neon 40 watt (Philips), toples, vial, cawan, cawan petri, corong, spatula, pipet tetes, kaca arloji, penangas air, mikropipet 10-100 $\mu \mathrm{L}$, timbangan analitik, kotak penampung larva (plastik), tabung reaksi, rotary evaporator (IKA RV 10 basic), hot plate dan stirrer, beaker gelas, gelas ukur, labu ukur, batang pengaduk, selang aerator, botol aqua, penjepit tabung reaksi, mesin pengaduk (IKA RW 20 Digital), corong Büchner (Rocker), kandang mencit

\section{Bahan dan hewan uji}

Umbi bawang tiwai, air suling, ragi, garam laut, etanol 90\%, $n$-heksana, Kloroform, aluminium foil, kertas saring. Hewan uji: mencit putih jantan

\section{B. Cara Kerja}

\section{Pembuatan Air Laut Buatan (ALB)}

Disiapkan air laut buatan dengan melarutkan $15 \mathrm{~g}$ natrium klorida dalam 1 L aquades. (Harmita dan Radji, 2008).

\section{Penetasan Telur A. salina Leach}

Telur udang ditetaskan sekitar 36-48 jam sebelum dilakukan pengujian toksisitas, wadah yang berbentuk kerucut yang bening atau transparan digunakan untuk penetasan telur udang kemudian ditambahkan air laut buatan telah diukur PH-nya (8-9), wadah tersebut diberi penerangan dengan cahaya lampu 40 Watt untuk menghangatkan suhu dalam penetasan agar suhu penetasan $25^{\circ} \mathrm{C}-31^{\circ} \mathrm{C}$ tetap terjaga dan merangsang proses penetasan dengan menggunakan aerator. Telur A. salina Leach 50-150 mg dicuci terlebih dahulu, yakni ditaburkan dan direndam pada wadah berisi aquades selama 1 jam setelah itu pada wadah berisi air laut buatan $500 \mathrm{~mL}$ dinyalakan aerator. Telur A. salina Leach dibiarkan selama 36-48 jam sampai menetas menjadi nauplii yang matang dan siap digunakan dalam percobaan. Telur akan menetas dalam waktu 18-48 jam dan akan bergerak secara alamiah menuju daerah terang sehingga larva udang terpisah dari kulit telur. Larva yang sehat bersifat 
fototropik dan siap dijadikan hewan uji pada umur 36-48 jam. Larva dipisahkan dari telurnya dengan pipet ke dalam vial yang berisi air laut buatan (Harmita dan Radji, 2008).

\section{Pembuatan Larutan Uji}

Vial disiapkan untuk tiap kelompok sesuai peringkat konsentrasi dengan masing-masing kemudian disediakan 8 vial dan direplikasikan sebanyak 3 kali Pada uji toksisitas ini dibuat larutan stok (induk) sebesar $10 \mathrm{mg}$ kemudian sampel dilarutkan dengan air laut buatan sampai $100 \mathrm{~mL}$. Pengujian dilakukan dengan menggunakan larutan uji yang dibuat dengan konsentrasi 0 ppm (kontrol negatif), $15,625 \mu \mathrm{g} / \mathrm{mL}, 31,25 \mu \mathrm{g} / \mathrm{mL}$, $62,5 \mu \mathrm{g} / \mathrm{mL}, 125 \mu \mathrm{g} / \mathrm{mL}, 250 \mu \mathrm{g} / \mathrm{mL}, 500$ $\mu \mathrm{g} / \mathrm{mL}$ dan $1000 \mu \mathrm{g} / \mathrm{mL}$ dalam air laut buatan. Setiap vial yang telah diisi sampel dengan volume $10 \mathrm{~mL}$ diisi 10 ekor larva $A$. salina Leach dan ditambahkan satu tetes suspensi ragi $(0,6$ $\mathrm{mg} / \mathrm{mL}$ ) sebagai makanannya (Harmita dan Radji, 2008). Uji kontrol negatif (blanko) diberi perlakuan sama seperti larutan uji tetapi tanpa ekstrak. Vial-vial tersebut diletakkan di bawah penerangan dengan lampu 40 Watt. Jumlah larva $A$. salina Leach yang mati dalam tiap vial selama 24 jam dihitung dengan cara manual. Pengamatan dilakukan selama 24 jam, tingkat toksisitas diperoleh dengan menghitung jumlah larva yang mati, yaitu bila larva udang tidak menunjukkan pergerakan selama beberapa detik observasi (Ramadhani, 2009).

\section{Uji Toksisitas Akut}

a. Pemilihan dan Penyiapan Hewan Uji

1) Pemilihan Hewan Uji

Hewan uji yang digunakan adalah mencit putih jantan sehat, aktivitas gerak lincah, bulunya bersih, umur 2-3 bulan dengan bobot badan mencit 20-30 gram.

2) Penyiapan Hewan Uji

Disiapkan 25 ekor mencit putih jantan. Mencit dibagi dalam 5 kelompok, yaitu 4 kelompok diberi larutan ekstrak fraksi kloroform dan 1 kelompok sebagai kontrol negatif. Tiap kelompok terdiri atas 5 ekor mencit jantan. Ditimbang berat badan selama seminggu sebelum dilakukan penelitian ketoksikan

b. Perlakuan Pada Hewan Uji

Hewan uji diberi larutan ekstrak fraksi kloroform secara oral sebanyak $0,5 \mathrm{ml} / 20 \mathrm{~g}$ berat badan dengan tingkat dosis I $(50 \mathrm{mg} /$ $\mathrm{KgBB})$, dosis II (100 mg/Kg BB), dosis III (200 mg/Kg BB), dan dosis IV (400 mg/Kg BB) serta kontrol negatif (CMC-Na 0,5\%). Ekstrak fraksi kloroform diberikan dengan cara disuspensikan dengan $\mathrm{CMC}-\mathrm{Na}$ $0,5 \%$

c. Pengujian

Dilakukan pengujian, kemudian diamati gejala keracunan yang mungkin timbul.

d. Pengamatan

1) Pengamatan sebelum diberikan perlakuan dilakukan selama 1 minggu dengan menimbang berat badan mencit. Hal ini dilakukan untuk memastikan mencit dalam keadaan baik dan sehat untuk digunakan sebagai hewan uji.

2) Pengamatan setelah diberi perlakuan yaitu pengamatan potensi ketoksikan akut, pengamatan ini dilakukan dengan melihat gejala-gejala fisik umum sebagai tanda keracunan yang timbul 
setelah pemberian ekstrak fraksi kloroform yang dibandingkan dengan kontrol negatif. Waktu pengamatan adalah menit ke 5, 10, 15, 30, 60, 120, 180 dan 240 (4 jam). Pengamatan dan perhitungan Nilai $\mathrm{LD}_{50}$ dilakukan terhadap mencit yang mati dan yang masih hidup selama 24 jam setelah pemberian ekstrak fraksi kloroform.

e. Pengumpulan Data

Data nilai $\mathrm{LD}_{50}$ diambil dari jumlah mencit yang mati dan masih hidup pada setiap kelompok, kemudian ditabulasi. Potensi ketoksikan akut ditentukan dari data mencit yang memperlihatkan gejala-gejala fisik umum sebagai tanda keracunan setelah pemberian larutan ekstrak fraksi kloroform yang dibandingkan dengan kontrol.

\section{f. Analisis Data}

Metode analisis yang digunakan untuk menentukan nilai $\mathrm{LD}_{50}$ dan potensi ketoksikan akut dari mencit yang mati dan hidup dari setiap kelompok adalah Metode Probit Miller Tainter, Weil CS dan Metode Farmakope Indonesia III.

\section{HASIL DAN PEMBAHASAN}

\section{A. Ekstraksi dan Fraksinasi Umbi Bawang Tiwai}

Didapatkan hasil ekstrak pekat berwarna merah kecoklatan sebanyak 50,41g (rendemen 10,082\%. Hasil fraksinasi menunjukkan perolehan rendemen fraksi $n$-heksan 8,26 g $(1,652 \%)$. fraksi kloroform 10,31 g (2,062\%), dan fraksi air 26,41 $\mathrm{g}(5,282 \%)$ terhadap serbuk umbi bawang tiwai.

\section{B. Pengujian BSLT}

Pengujian BSLT merupakan uji toksisitas akut yang dilakukan untuk menentukan efek toksik setelah pemberian dosis dalam waktu 24 jam. Pengujian hasil BSLT menunjukkan bahwa ekstrak etanol memiliki toksisitas $\mathrm{LC}_{50}=66,68 \mathrm{ppm}$ (kategori sangat toksik), fraksi $n$-heksana memiliki toksisitas $\mathrm{LC}_{50}=47,64 \mathrm{ppm}$ (kategori sangat toksik), fraksi kloroform memiliki toksisitas $\mathrm{LC}_{50}=295,1 \mathrm{ppm}$ (kategori toksik), dan fraksi air memiliki toksisitas $\mathrm{LC}_{50}=194,54 \mathrm{ppm}$ (kategori sangat toksik).

Tabel 1. Hasil Pengujian BSLT

\begin{tabular}{|c|c|c|c|c|c|c|}
\hline $\begin{array}{c}\text { Kelompok } \\
\text { uji }\end{array}$ & $\begin{array}{c}\text { Konsentrasi } \\
(\mathbf{p p m})\end{array}$ & $\begin{array}{c}\text { Log } \\
\text { Konsentrasi }\end{array}$ & $\begin{array}{c}\text { Jml } \\
\text { Mati }\end{array}$ & \% mati & Probit & LC50 (ppm) \\
\hline \multirow{4}{*}{$\begin{array}{c}\text { Ekstrak } \\
\text { Etanol }\end{array}$} & 20 & 1.301 & 2 & 10 & 3.72 & \multirow{2}{*}{} \\
\cline { 2 - 6 } & 40 & 1.602 & 6 & 30 & 4.48 & \multirow{2}{*}{$6 \mathbf{6 6 , 6 8}$} \\
\cline { 2 - 6 } & 160 & 1.903 & 8 & 40 & 4.75 & \\
\cline { 2 - 6 } & 320 & 2.204 & 16 & 80 & 5.84 & \multirow{2}{*}{$\mathbf{4 7 , 6 4}$} \\
\hline \multirow{3}{*}{$\begin{array}{c}\text { Fraksi } \\
\text { n-Heksan }\end{array}$} & 20 & 1.301 & 2 & 10 & 3.72 & \\
\cline { 2 - 6 } & 40 & 1.602 & 5 & 25 & 4.33 & \\
\hline
\end{tabular}




\begin{tabular}{|c|c|c|c|c|c|c|}
\hline & 160 & 2.204 & 15 & 75 & 5.67 & \\
\hline & 320 & 2.505 & 20 & 100--99 & 7.33 & \\
\hline \multirow{5}{*}{$\begin{array}{c}\text { Fraksi } \\
\text { Kloroform }\end{array}$} & 20 & 1.301 & 1 & 5 & 3.36 & \multirow{5}{*}{295,12} \\
\hline & 40 & 1.602 & 3 & 15 & 3.96 & \\
\hline & 80 & 1.903 & 5 & 25 & 4.33 & \\
\hline & 160 & 2.204 & 8 & 40 & 4.75 & \\
\hline & 320 & 2.505 & 12 & 60 & 5.25 & \\
\hline \multirow{5}{*}{ Fraksi Air } & 20 & 1.301 & 1 & 5 & 3.36 & \multirow{5}{*}{194,54} \\
\hline & 40 & 1.602 & 4 & 20 & 4.16 & \\
\hline & 80 & 1.903 & 6 & 30 & 4.48 & \\
\hline & 160 & 2.204 & 9 & 45 & 4.87 & \\
\hline & 320 & 2.505 & 12 & 60 & 5.25 & \\
\hline
\end{tabular}

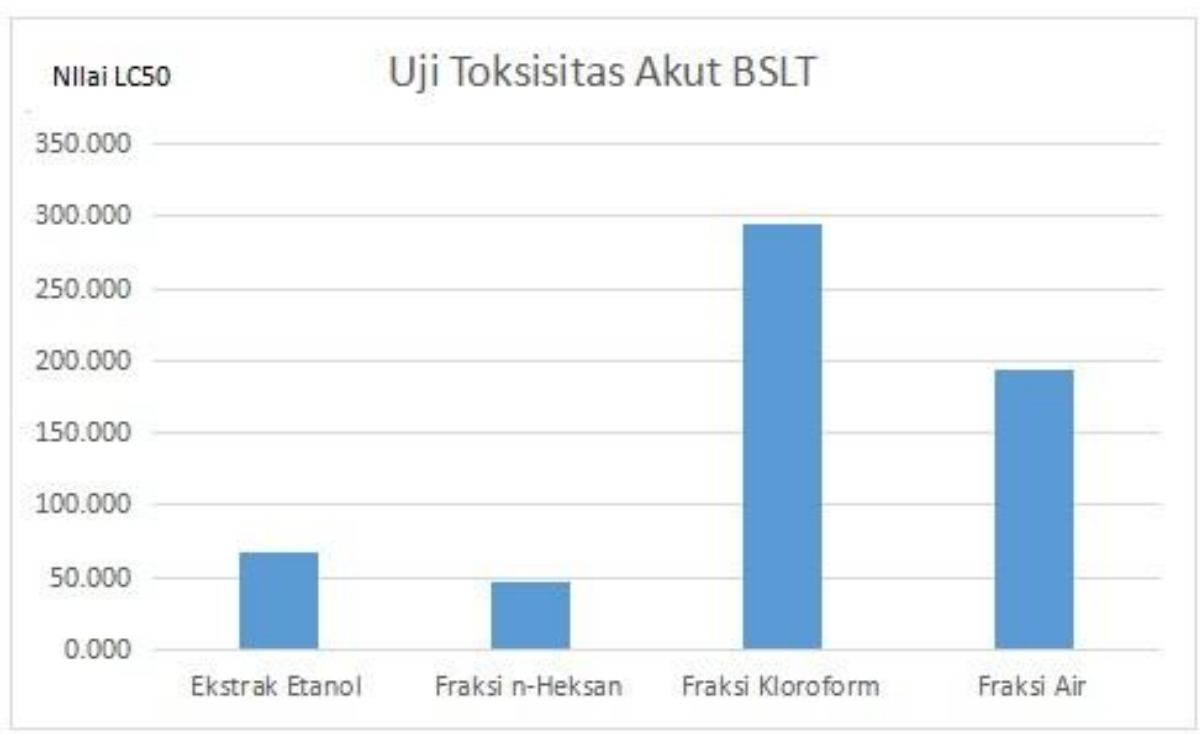

\section{Gambar 1. Nilai $\mathrm{LC}_{50}$ (Letal Consentration)}

Hasil yang didapatkan pada uji BSLT ini adalah pada dimana nilai $\mathrm{LC}_{50}$ yang diperoleh sebesar 295,12 ppm yang paling tinggi dan termasuk kategori toksik (250-500 ppm). Berdasarkan hasil uji toksisitas diketahui bahwa racun yang dihasilkan oleh dosis tunggal dari fraksi kloroform pada hewan coba sebagai uji pra-skrinning senyawa bioaktif antikanker dimana menunjukan bahwa komponen bioaktifnya bersifat toksik jika diberikan pada dosis tinggi, akan tetapi akan menjadi obat jika diberikan pada dosis rendah atau dosis yg terukur, artinya walaupun bersifat toksik masih dapat digunakan sebagai obat antikanker dengan kombinasi bersama vitamin, untuk mengurangi efek dari racun tersebut.

C. Pengujian Uji toksisitas akut Fraksi Kloroform Umbi Bawang Tiwai pada mencit putih jantan (Mus musculus L) 
Aklimatisasi dilakukan dengan tujuan agar semua kelompok menerima keadaan dan situasi yang sama dalam proses penyesuaian terhadap lingkungan.
Hari ke-1 sampai hari ke-7 semua hewan uji ditimbang untuk mengetahui kesehatan dengan melihat bobot pada mencit.

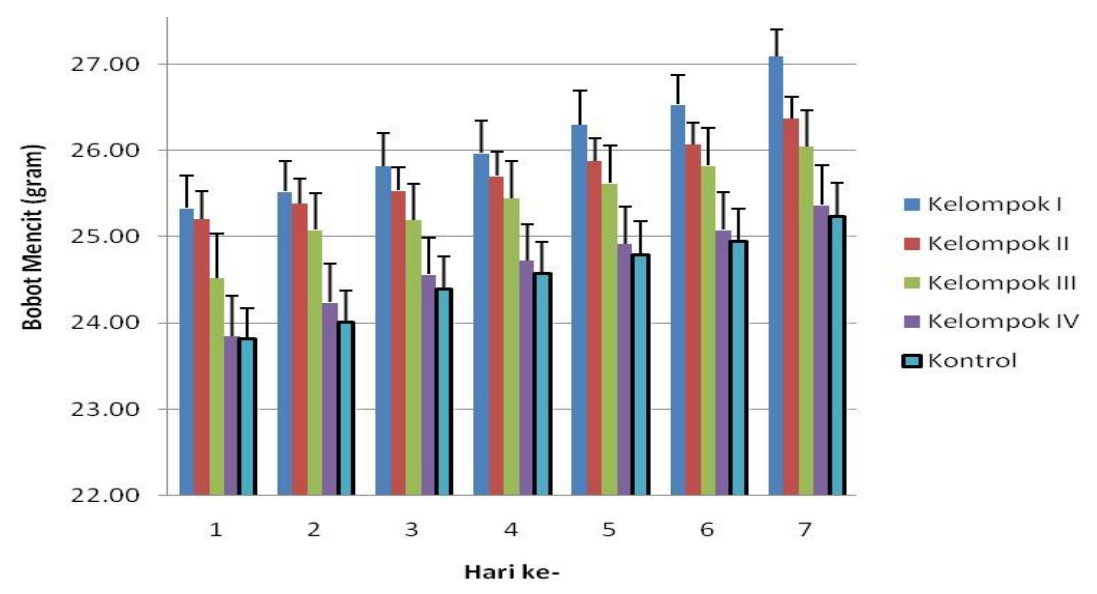

Gambar 2. Grafik Penimbangan Bobot Mencit

Pada gambar 2 dapat dilihat bahwa terjadi peningkatan bobot mencit setiap harinya, dengan SEM (Standart Erorr of Mean) yaitu varian bobot mencit dalam 1 kelompok, menunjukkan selisih yang kecil $(\mathrm{p}>0,05)$ atau tidak jauh berbeda dalam 1 kelompok sehingga disimpulkan bobot mencit termasuk homogen. Kenaikan bobot mencit merupakan salah satu hal yang dapat menunjukkan bahwa mencit tersebut dalam keadaan sehat dan dapat digunakan sebagai hewan percobaan.
Hewan uji dipuasakan selama 3 jam sebelum pemberian dan selama 12 jam setelah pemberian ekstrak, hal ini dilakukan agar makanan yang ada di saluran cerna mencit tidak mempengaruhi efek dari ekstrak yang dipejankan pada mencit. Hewan uji diberikan dengan sediaan uji dalam dosis tunggal secara oral, cara ini dilakukan sama seperti bagaimana manusia dapat mengalami keracunan, yaitu melalui mulut dengan diberikan sediaan uji dalam bentuk larutan.

Tabel 3. Gejala Sebagai Tanda Keracunan Setelah Pemberian

\begin{tabular}{|c|c|c|c|c|}
\hline & Kelompok & Perlakuan & Jumlah & $\begin{array}{l}\text { Gejala } \\
\text { Keracunan }\end{array}$ \\
\hline \multirow{5}{*}{ II } & Kontrol & & & \\
\hline & Kelompok I & $\mathrm{CMC} \mathrm{Na} 0.5 \%$ & 5 & Tidak ada \\
\hline & Kelompok & Dosis $50 \mathrm{mg} / \mathrm{kgBB}$ & 5 & Tidak ada \\
\hline & & Dosis $100 \mathrm{mg} / \mathrm{kgBB}$ & 5 & Tidak ada \\
\hline & Kelompok & Dosis $200 \mathrm{mg} / \mathrm{kgBB}$ & 5 & Tidak ada \\
\hline III & Kelompok & Dosis $400 \mathrm{mg} / \mathrm{kgBB}$ & 5 & Tidak ada \\
\hline
\end{tabular}


Hasil pengamatan pada tabel 3 menunjukkan bahwa hewan uji tidak mengalami gejala umum sebagai tanda keracunan. Pada pengamatan setelah pemberian ekstrak fraksi kloroform umbi bawang tiwai, gejala keracunan yang diamati tersebut adalah ciri-ciri yang mempengaruhi prilaku, syaraf otot, syaraf otonom, pernafasan, gastrointestinal, dan kulit. Perlakuan pada kelompok I sampai IV terjadi gejala yang mempengaruhi prilaku (menunduk, menggaruk-garuk dan ketakutan) dan syaraf otot (ekor membengkok), tetapi gejala tersebut juga terjadi pada kelompok kontrol sehingga tidak dapat dikategorikan sebagai gejala tanda keracunan.

Uji LD $_{50}$ terhadap ekstrak fraksi kloroform dilakukan untuk mengetahui pada dosis berapa ekstrak fraksi kloroform dapat memberikan efek toksik. Efek tersebut ditandai dengan adanya kematian pada mencit yang telah diberikan ekstrak fraksi kloroform, yang diamati selama 4 jam untuk mengetahui gejala keracunan dan dilanjutkan pengamatan selama 24 jam untuk melihat adanya kematian. (Ngatidjan, 1997).

Tabel 4. Jumlah kematian setelah 24 jam pemberian ekstrak

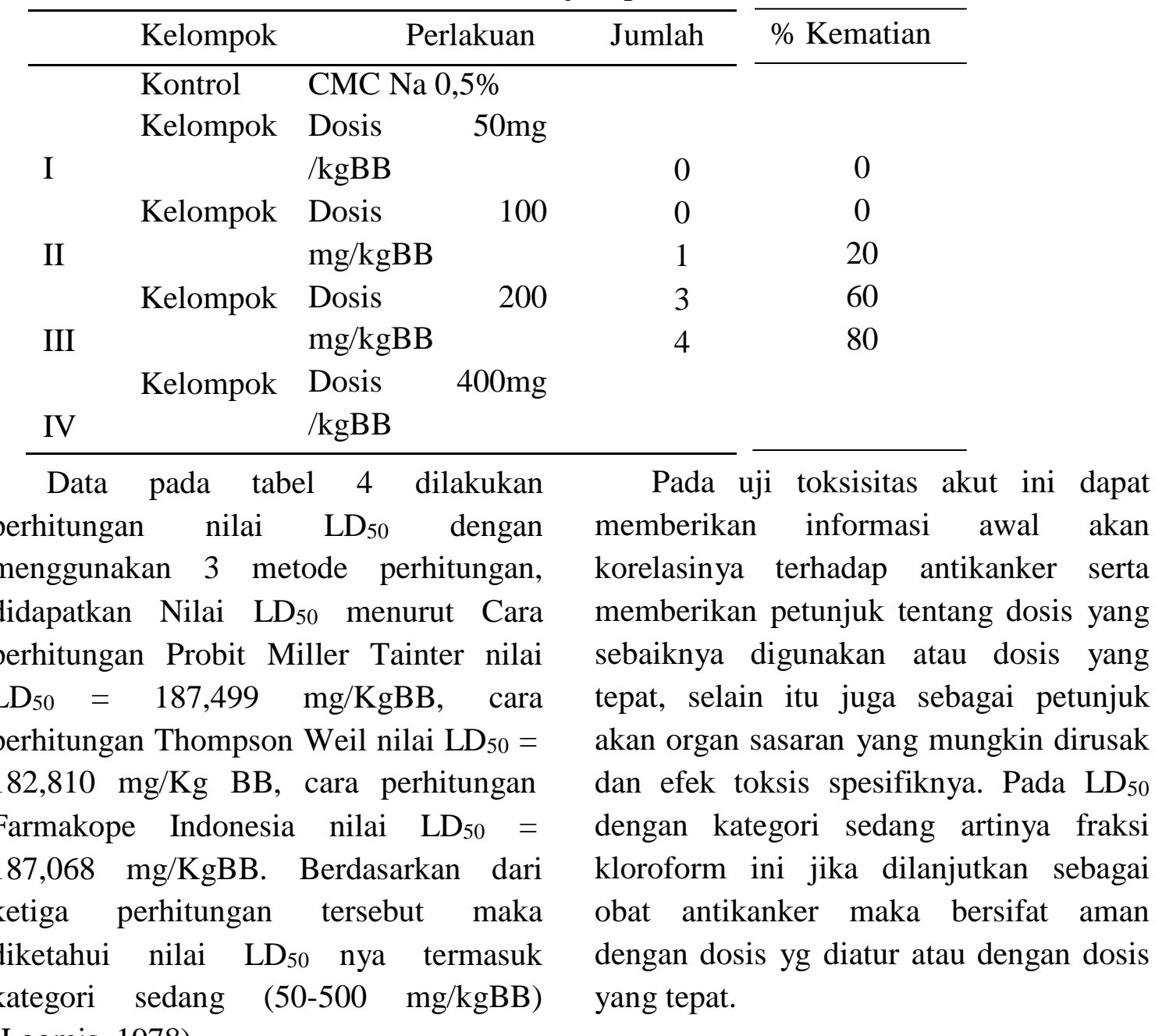

(Loomis, 1978). 


\section{SIMPULAN}

1. Pengujian hasil BSLT menunjukkan bahwa ekstrak etanol memiliki toksisitas $\quad \mathrm{LC}_{50}=66,68 \mathrm{ppm}$ (kategori sangat toksik), fraksi n-heksana memiliki toksisitas $\mathrm{LC}_{50}$ $=47,64 \mathrm{ppm}$ (kategori sangat toksik), fraksi kloroform memiliki toksisitas $\mathrm{LC}_{50}=295,1 \mathrm{ppm}$ (kategori toksik), dan fraksi air memiliki toksisitas $\mathrm{LC}_{50}$ $=194,54 \mathrm{ppm}$ (kategori sangat toksik).

2. Fraksi kloroform merupakan fraksi aktif, hasil uji Ketoksikan akut Nilai $\mathrm{LD}_{50}$ menurut cara perhitungan Probit Miller Tainter $(187,499$ $\mathrm{mg} / \mathrm{KgBB}$ ), cara perhitungan Thompson Weil $(182,810$ $\mathrm{mg} / \mathrm{KgBB})$, cara perhitungan Farmakope Indonesia (187,068 $\mathrm{mg} / \mathrm{KgBB})$. Berdasarkan dari ketiga perhitungan tersebut maka diketahui nilai $\mathrm{LD}_{50}$ nya termasuk kategori sedang (50-500 mg/kgBB).

\section{DAFTAR PUSTAKA}

Amanda, F. R. 2014.'Efektivitas Ekstrak Bawang Dayak (Eleutherine palmifolia L. Merr) dalam Menghambat Pertumbuhan Bakteri Escherichia coli”. Laporan Penelitian. Jakarta: Fakultas Kedokteran dan Ilmu Kesehatan Universitas Islam Negeri Syarif Hidayatullah. Hal: 7

Carballo, J. L. I., Inda, Z. L. H., Perez. 2002."A Comparison between Two Brine Shrimp Assay to Detect in Vitro Cytotoxicity in Marine Natural Product". BMC Biotecnology. 2 (17): $1-5$.
Febrinda, A. E., Astawan, M., Wresdiyati, T., Yuliana, N. D. 2013.'Kapasitas Antioksidan dan Inhibitor Alfa Glukosidase Ekstrak Umbi Bawang Dayak". Jurnal Teknologi dan Industri Pangan. 24(2). Hal: 161

Galingging, R.Y. 2009.'Bawang Dayak (Eleutherine palmifolia) Sebagai Tanaman Obat Multifungsi”. Warta Penelitian dan Pengembangan. 15(3): 16-18

Harmita dan Radji, M. 2008. Analisis Hayati. Jakarta: Penerbit Buku Kedokteran. Hal: 76-78

Kuntorini, E. M., Astuti, M. D., Nugroho, L. H. 2010."Struktur Anatomi dan Aktivitas Antioksidan Bulbus Bawang Dayak (Eleutherine americana Merr) Dari Daerah Kalimantan Selatan". Penelitian Hayati. (16): 1-7.

Loomis, T.A. 1978. Toksikologi Dasar. Diterjemahkan oleh Donatos, I. A. Semarang: IKIP Semarang Press

Meyer, B. N., Ferrigni, N. R., Putnam, J. E., Jacobsen, L. B., Nicholas, D. E. Dan Mc Laughlin, J. L. 1982.’Brine Shrimp: A Convenient General Bioassay for Active Plant Constituent". Drug Information Journal. (45): 31-34

Priyanto. 2009. Toksikologi Mekanisme Terapi Antidotum dan Penilaian Resiko. Jakarta: Lembaga Studi dan Konsultasi Farmakologi. Hal: 
$156-167$

Ramadhan, B.K., dan Schaalan, M.F., 2011, The Renoprotective Effect of Honey on Paracetamol-Induced Nephrotoxicity In Adult Male Albino Rats, Life Science Journal 8 (3).

Saptowaluyo, C.A. 2007. Bawang Dayak, Tanaman Obat Kanker yang Belum

Tergarap. http//www.kompas.com. 